\title{
WATER AVAILABILITY AND POTASSIUM DOSES IN CHERRY TOMATO QUALITY
}

\author{
Tonny J. A. da Silva ${ }^{1}$, Adriano B. Pacheco ${ }^{1}$, Edna M. Bonfim-Silva ${ }^{2 *}$, Thiago F. Duarte ${ }^{1}$
}

${ }^{2 *}$ Corresponding author. Federal University of Mato Grosso, Institute of Agricultural Sciences and Technology/

Rondonópolis - MT, Brazil. E-mail: embonfim@hotmail.com

\section{KEYWORDS}

Soil water, Diviner

2000, Lycopersicon esculentum Mill.

\begin{abstract}
The quality of cherry tomato fruits is directly related to the management strategies used in the production system, such as irrigation and fertilization. This study aimed to assess the quality of cherry tomato fruits cultivated under water availability and potassium fertilization. The experiment was carried out in a greenhouse in pots of $12 \mathrm{dm}^{3}$ of an Oxisol. The experimental design was a randomized block design in a $5^{2}$ fractional factorial arrangement with five water availabilities in the soil $(4,14,24,34$, and $44-\mathrm{kPa})$, five potassium doses $\left(0,125,250,375\right.$, and $\left.500 \mathrm{mg} \mathrm{dm}^{-3}\right)$ and with four blocks. Irrigation was performed with a semi-automated drip irrigation system with soil moisture monitoring by the Diviner $2000^{\circledR}$ capacitance probe. The assessed variables in fruits were longitudinal and transversal diameter and pulp thickness, fruit shape index, total soluble solids (SS), titratable acidity (TA), the SS/TA ratio, and vitamin C. The data were submitted to statistical analyses at 5\% probability error, with analysis of variance by the F-test and polynomial regression. Fruit size presents a reduction as water availability decreased. The total soluble solids have a higher concentration at a potassium dose of 326 $\mathrm{mg} \mathrm{dm}{ }^{-3}$. The quality of cherry tomato fruits cultivated in an Oxisol is influenced by water availability and potassium doses.
\end{abstract}

\section{INTRODUCTION}

Cherry tomato (Lycopersicon esculentum Mill.) has a characteristic flavor, which is outstanding in the specialized cooking, and a high added value due to the high quality of fruits required by consumers. Thus, the cherry tomato is as a good alternative of profitability for producers since its plants have a good adaptation to different productive systems, with less use of fertilizers and pesticides, especially in protected cultivation (Rocha et al., 2010; Lúcio et al., 2016; Sari et al., 2017).

Among the main indicators used to measure the quality of tomato fruit, the most relevant are those related to appearance, size, and flavor. At the time of purchase, the appearance and pattern of structural characteristics of fruits are the main criteria adopted by consumers. However, according to Yuri et al. (2016), the total soluble solids (SS), titratable acidity (TA), and the SS/AT ratio are the main variables analyzed to assess fruit flavor quality.

The irrigation of tomatoes is managed mainly for a high productivity, being fruit quality, in some cases, neglected in the management strategies. According to Chen et al. (2013), fruit quality is directly affected when tomato plants suffer some water deficit, mainly in fruit formation. Thus, the water restriction applied at the maturation stage of fruits may lead to gains in quality parameters.

The characteristics of cherry tomato fruits are also influenced by soil fertility, especially the availability of potassium. This nutrient plays important roles in plants, such as osmotic regulation, enzyme activation, photoassimilate transport, carbon dioxide assimilation, and transpiration (Pervez et al, 2004; Coskun et al. 2016; Ziaul-Hassan et al., 2016), being directly related to fruit quality.

Considering that, the aim of this study was to assess the quality of cherry tomato fruits cultivated under water availability and potassium doses in a pot containing Oxisol under a protected environment.

\section{MATERIAL AND METHODS}

The experiment was carried out at the Institute Institute of Agricultural and Technology of the Federal University of Mato Grosso, Rondonópolis, MT, Brazil,

${ }^{1}$ Federal University of Mato Grosso, Institute of Agricultural Sciences and Technology/ Rondonópolis - MT, Brazil.

Received in: 10-23-2017

Accepted in: 8-3-2018 
located at the geographical coordinates $16^{\circ} 27^{\prime} 51^{\prime \prime} \mathrm{S}$ and $54^{\circ} 34^{\prime} 50^{\prime \prime} \mathrm{W}$, with an altitude of $284 \mathrm{~m}$.

The experimental design was a randomized block design with five soil water availabilities as a function of soil water tension $(4,14,24,34$, and $44-\mathrm{kPa})$ and five potassium doses $\left(0,125,250,375\right.$, and $\left.500 \mathrm{mg} \mathrm{dm}^{-3}\right)$. The experiment was arranged in a $5^{2}$ fractional factorial arrangement based on the central composite adapted from Littell \& Mott (1975), resulting in 13 treatments $(4 \mid 0$, $4|250,4| 500,14|125,14| 375,24|0,24| 250,24|500,34| 125$, $34|375,44| 0,44 \mid 250$, and $44|500-\mathrm{kPa}| \mathrm{mg} \mathrm{dm}^{-3}$ ), with four replications.

The soil was collected at a depth of $0.0-0.2 \mathrm{~m}$ in a Cerrado area and was classified as an Oxisol (Brazilian Soil Classification, Latossolo Vermelho distrófico). Subsequently, this soil was sieved in a $2 \mathrm{~mm}$ sieve for chemical and particle size characterization (EMBRAPA, 1997) and in a $4 \mathrm{~mm}$ sieve for liming and pot accommodation.

The soil presented the following characteristics after chemical and particle size analyses: $\mathrm{pH}\left(\mathrm{CaCl}_{2}\right)=4.0$, $\mathrm{P}=1.4 \mathrm{mg} \mathrm{dm}^{-3}, \mathrm{~K}=23 \mathrm{mg} \mathrm{dm}{ }^{-3}, \mathrm{Ca}=0.4 \mathrm{cmol}_{\mathrm{c}} \mathrm{dm}^{-3}$, $\mathrm{Mg}=0.2 \mathrm{cmol}_{\mathrm{c}} \mathrm{dm}^{-3}, \mathrm{Al}=0.8 \mathrm{cmol}_{\mathrm{c}} \mathrm{dm}^{-3}, \mathrm{H}=5.4 \mathrm{cmol}_{\mathrm{c}}$ $\mathrm{dm}^{-3}, \mathrm{OM}=27.1 \mathrm{~g} \mathrm{dm}^{-3}, \mathrm{SB}=0.7 \mathrm{cmol}_{\mathrm{c}} \mathrm{dm}^{-3}, \mathrm{CEC}=6.8$ $\mathrm{cmol}_{\mathrm{c}} \mathrm{dm}^{-3}, \mathrm{~V}=9.7 \%$, sand $=423 \mathrm{~g} \mathrm{~kg}^{-1}$, silt $=133 \mathrm{~g} \mathrm{~kg}^{-1}$, and clay $=444 \mathrm{~g} \mathrm{~kg}^{-1}$. Liming was performed with dolomitic limestone (TNP $80.3 \%$ ) to raise base saturation to $80 \%$. After the 40 -day reaction period, the $\mathrm{pH}\left(\mathrm{CaCl}_{2}\right)$ increased to 6.8 .

Fertilizations with macro and micronutrients were adapted from Alvarenga (2013) (Table 1), considering that the volume of soil to be exploited by the root system would be limited. In this sense, all recommended fertilizations were split (Figure 1) to avoid possible risks of salinization, in addition to balancing nutrients with the use of different sources.

TABLE 1. Recommendation and sources for fertilization with macronutrients and micronutrients.

\begin{tabular}{|c|c|c|c|c|c|}
\hline & & & imendatio & & \\
\hline \multirow{2}{*}{ Macronutrients } & $\mathbf{N}^{\mathbf{C , D , G}}$ & $\mathbf{P}^{\mathrm{A}, \mathrm{C}}$ & $\mathrm{Ca}^{\text {B,E,G }}$ & $\operatorname{Mg}^{\text {B,F }}$ & $\mathbf{S}^{\mathbf{A}, \mathbf{F}}$ \\
\hline & 200 & 387 & 1400 & 795 & 220.8 \\
\hline \multirow{2}{*}{ Micronutrients } & $\mathrm{B}^{\mathrm{H}}$ & $\mathrm{Cu}^{\mathrm{I}}$ & $\mathbf{M n}^{\mathrm{J}}$ & Mo $^{\mathrm{K}}$ & $\mathbf{Z n}^{\mathrm{L}}$ \\
\hline & 1.5 & 1.5 & 3.0 & 0.3 & 3.0 \\
\hline
\end{tabular}

Sources used: A - simple superphosphate incorporated into the soil at the transplanting time; B - dolomitic limestone applied in the liming; $\mathrm{C}$ - monoammonium phosphate (PA); D - urea; E - calcium chloride (PA); F - magnesium sulfate (PA); G - calcium nitrate; H - boric acid (PA); I - copper sulfate; $\mathrm{J}$ - manganese sulfate; $\mathrm{K}$ - molybdic acid; $\mathrm{L}$ - zinc sulfate.

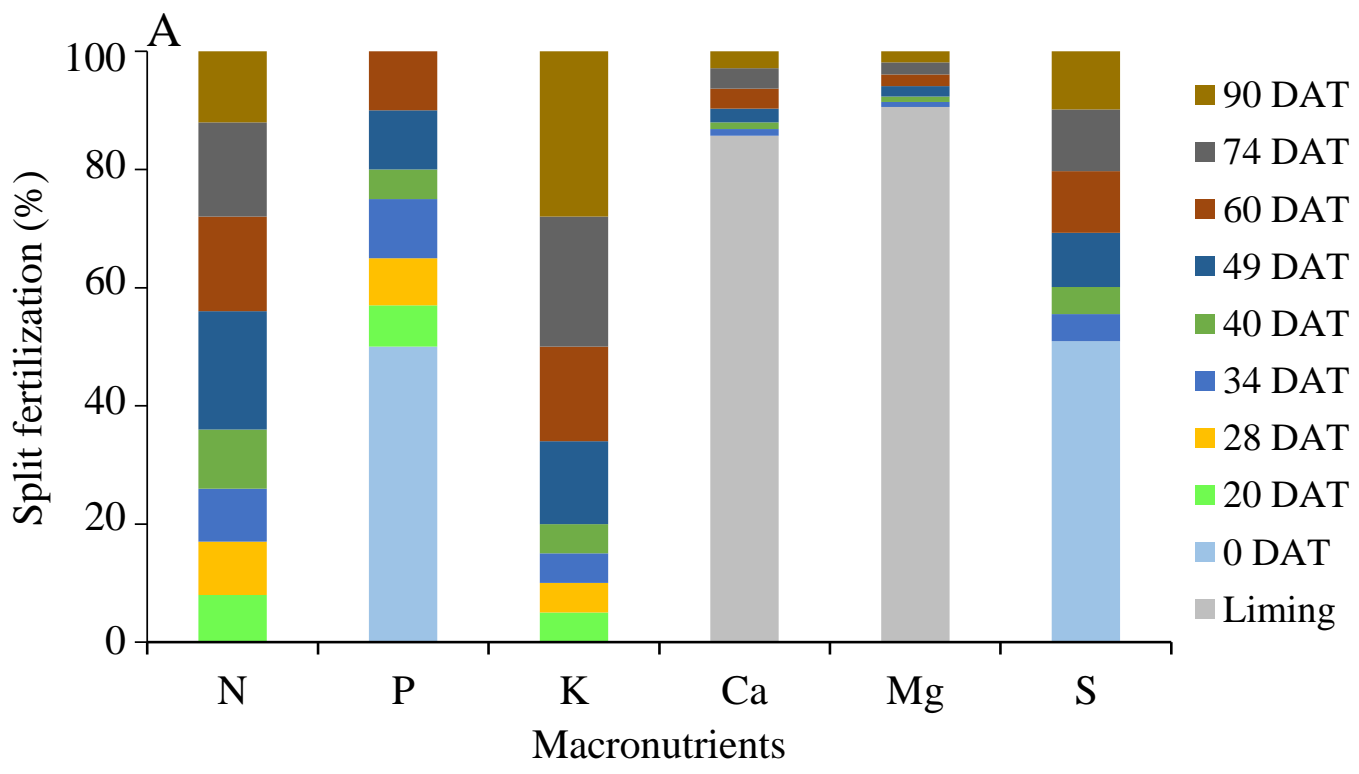




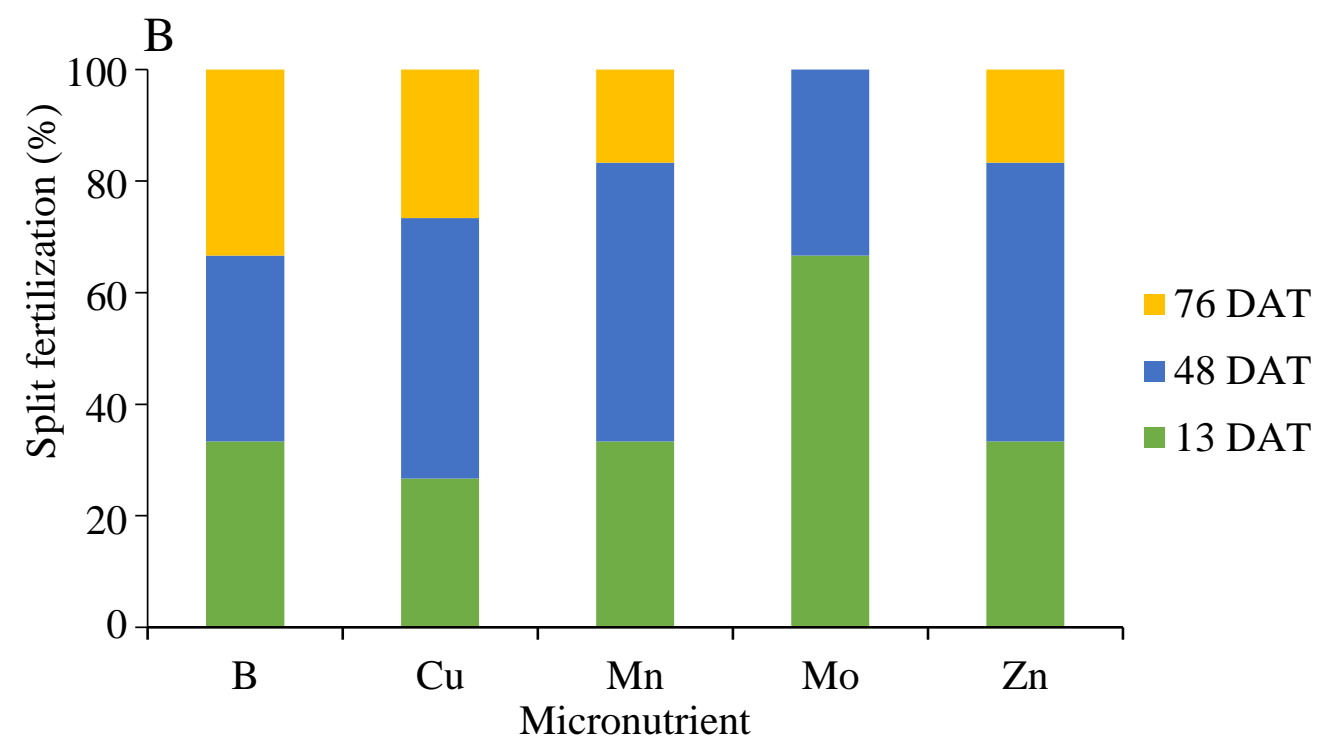

FIGURE 1. Split of the recommended fertilization with macronutrients (A) and micronutrients (B) for cherry tomatoes. DAT days after transplanting.

The experimental units were made with PVC pipes with a diameter of $20 \mathrm{~cm}$ and a height of $40 \mathrm{~cm}$. At a height of $25 \mathrm{~cm}$, holes of $5 \mathrm{~cm}$ in diameter were made to install the access tube, which allowed monitoring the soil moisture with the Diviner $2000^{\circledR}$ capacitance probe. Subsequently, the experimental units were filled with $12 \mathrm{dm}^{3}$ of soil per pot.
The access tubes were installed horizontally with four pots per tube for using the Diviner $2000^{\circledR}$ probe, as in Pereira et al. (2016). Considering readings performed every $0.1 \mathrm{~m}$, pots with a diameter of $0.2 \mathrm{~m}$, and a space between pots of $0.1 \mathrm{~m}$, each profile provided four usual readings at the center of each pot (Figure 2).
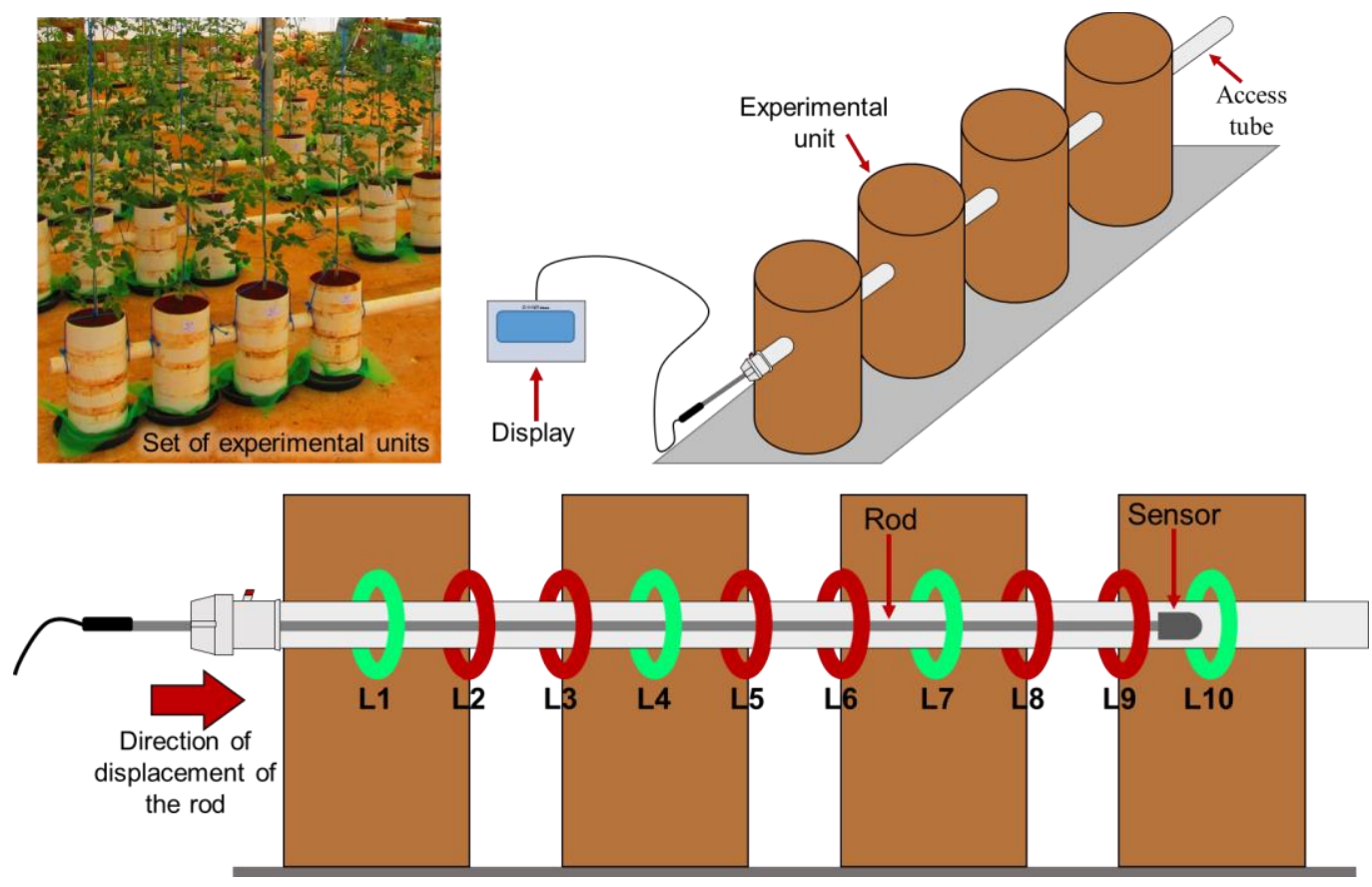

FIGURE 2. Set of experimental units and representation of soil moisture monitoring with the capacitance probe with usual (L1, L4, L7, and L10) and unusual readings (L2, L3, L5, L6, L8, and L9).

A previous calibration was performed to determine the relationship between soil water tension and volumetric moisture, as well as the relationship between the volumetric moisture obtained with the capacitance probe and the standard volumetric moisture.

The relationship between the standard volumetric moisture and soil water tension (Equation 1) $\left(\mathrm{R}^{2}=0.97\right)$ was used to determine the water availability considering the soil water tension specified by the treatment (Table 2).

$$
\theta=0.5994 \times \mathrm{T}^{-0.418}
$$

Where, 
$\theta$ is the soil volumetric moisture obtained by the standard method $\left(\mathrm{cm}^{3} \mathrm{~cm}^{-3}\right)$ and $\mathrm{T}$ is the soil water tension $(-\mathrm{kPa})$.

TABLE 2. Soil volumetric moisture as a function of each treatment of water availability according to the soil water tension $\left(\theta=0.5994 * * * \mathrm{~T}^{-0.418}\right)$.

\begin{tabular}{c|c|c|c|c|c}
\hline $\begin{array}{c}\text { Soil tension } \\
(-\mathrm{kPa})\end{array}$ & 4 & 14 & 24 & 34 & 44 \\
\hline $\boldsymbol{\theta ( \mathbf { c m } ^ { \mathbf { 3 } } \mathbf { ~ c m } ^ { \mathbf { - 3 } } )}$ & $\mathbf{0 . 3 3 5 7}$ & $\mathbf{0 . 1 9 8 9}$ & $\mathbf{0 . 1 5 8 9}$ & $\mathbf{0 . 1 3 7 3}$ & $\mathbf{0 . 1 2 3 2}$ \\
\hline
\end{tabular}

In the experiment, a daily irrigation management was carried out by monitoring soil moisture with the capacitance probe. Thus, the volumetric moisture for determining the irrigation water depth per experimental unit was obtained by the relationship between the standard volumetric moisture and the volumetric moisture of the capacitance probe (Equation 2) $\left(\mathrm{R}^{2}=97.3\right)$.

$$
\theta \quad=\quad \begin{array}{llll}
1.0737 & \theta_{\text {Diviner2000 }} & - & 0.006
\end{array}
$$

Where,

$\theta$ is the soil volumetric moisture obtained by the standard method $\left(\mathrm{cm}^{3} \mathrm{~cm}^{-3}\right)$, and

$\theta_{\text {Diviner2000 }}$ is the volumetric moisture of the Diviner
$2000^{\circledR}$ capacitance probe $\left(\mathrm{cm}^{3} \mathrm{~cm}^{-3}\right)$.

Based on the soil volumetric moisture (standard) and the soil volume in the pot, the required water depth was calculated (Equation 3) to reach the desired volumetric moisture (Table 2) according to the treatment of water availability.

$$
\begin{aligned}
& \mathrm{V} \\
& (3)
\end{aligned}
$$

Where,

$\mathrm{V}$ is the water volume $\left(\mathrm{cm}^{3}\right)$;

$\theta$ treat is the desired volumetric moisture according to the treatments $\left(\mathrm{cm}^{3} \mathrm{~cm}^{-3}\right)$ (Table 2), and

$\theta$ current is the current volumetric moisture $\left(\mathrm{cm}^{3}\right.$ $\left.\mathrm{cm}^{-3}\right)$.

Irrigation was performed with a semi-automated drip irrigation system. This system consisted of a $1000 \mathrm{~L}$ tank with a hydraulic float, a motor pump of $0.5 \mathrm{HP}$, a 125 micron (120 mesh) disc filter, a ball valve, a manometer at the exit of the control stand, PVC pipes and fittings (polyvinyl chloride), solenoid valves, relief valves on the control stand and at the end of the lines, pressure regulator, microtube, and self-compensating dripper of $4 \mathrm{~L} \mathrm{~h}^{-1}$.

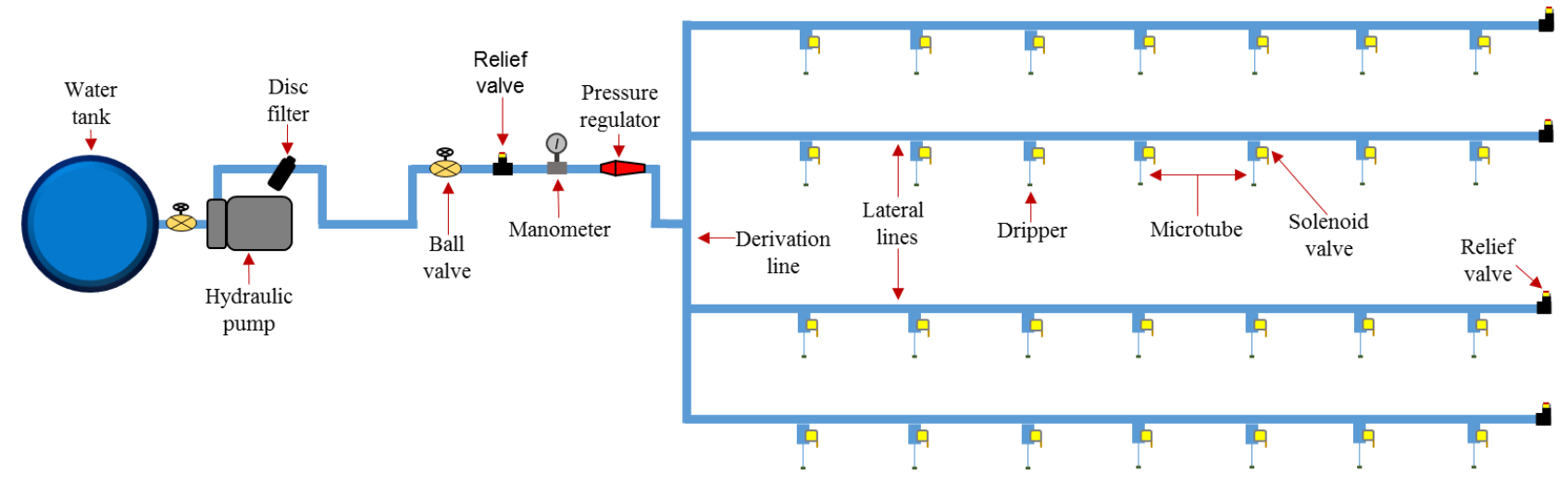

FIGURE 3. Components of the irrigation system.

Solenoid valve actuation was performed by serial relay modules, which were controlled by a RoboCore ${ }^{\circledR}$ BlackBoard Arduino board. The software used by the controller had its architecture developed in the Arduino platform environment. The computer interface for communication with the controller software was developed to allow the scheduling of the irrigation time from the data input of flow of each dripper, water volume to be applied per experimental unit, and irrigation start time. For communication safety, the computer interface resent the programming sequence to the controller every second in case of a power failure.

Cherry tomato seedlings were produced in styrofoam trays filled with commercial substrate and vermiculite in the $1: 1$ ratio, in which one seed of the cultivar BRS Iracema was sown per cell. Transplanting was carried out when seedlings presented three to four definitive leaves, leaving one seedling per pot.

At seven days after transplanting, the treatments were differentiated according to the water availabilities. Plants were conducted using a narrow ribbon and single stem to about two meters in height in relation to the neck of the plant, from the elimination of side sprouts (Marim et al., 2005; Viol et al., 2017).

Fruits were harvested periodically according to ripening, with fruits presenting a red external coloration. The structural characteristics assessed in the fruits were the average longitudinal and transversal diameter of all fruits produced in the cycle and the pulp thickness sampled in about $20 \%$ of the produced fruits. These measurements were obtained with an analog caliper and the data were expressed in $( \pm 0.05) \mathrm{mm}$. The shape index was calculated by the ratio of longitudinal/transversal diameters. 
The content of soluble solids (SS) was determined with a portable refractometer (LI, Model 2159), being expressed in ${ }^{\circ}$ Brix $( \pm 0.5)$. The titratable acidity (TA) was assessed by titration with sodium hydroxide at a concentration of $0.1 \mathrm{M}$ and expressed in $\mathrm{g}$ citric acid 100 $\mathrm{mL}^{-1}$ of pulp. In order to establish the balance between sugar content and acidity of fruits, the SS/TA ratio was determined. Vitamin $\mathrm{C}$ was determined by titration with potassium iodate at a concentration of $0.002 \mathrm{M}$ and expressed in $\mathrm{mg} 100 \mathrm{~g}^{-1}$ of pulp (Pregnolatto \& Pregnolatto, 1985). For the parameters determined by titration, a graduated burette of $25( \pm 0.5) \mathrm{mL}$ was used. Twelve fruits were sampled per experimental unit for determining the soluble solids and six fruits per experimental unit for titratable acidity and vitamin $\mathrm{C}$, throughout the crop cycle.

The data were submitted to the analysis of variance

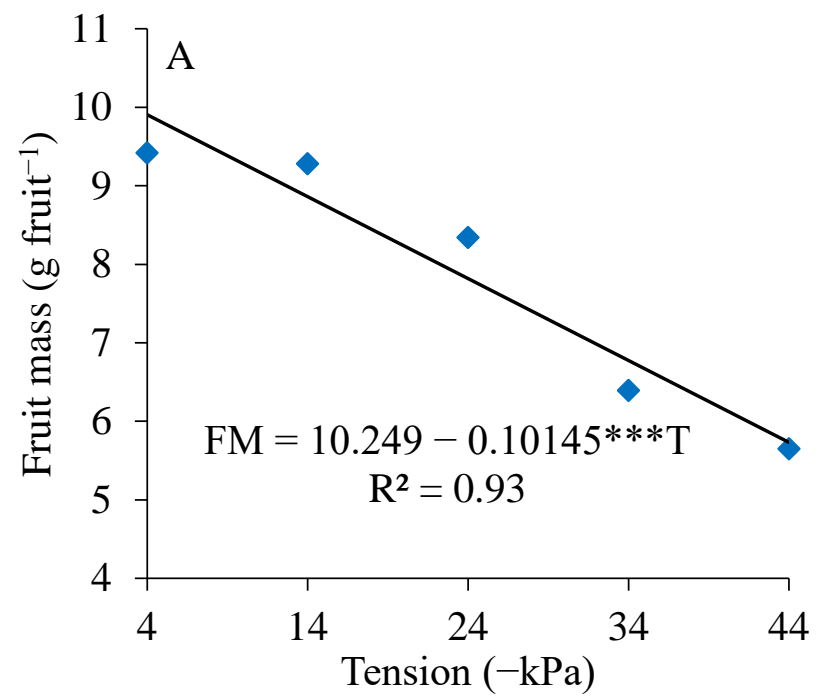

FIGURE 4. Fruit mass (FM) (A) and pulp thickness (PT) availabilities in an Oxisol. ***Significant at $0.1 \%$.

Fruit fresh mass presented a similar behavior to those observed by Candido et al. (2015), who observed an increase in fruit fresh mass as the water depth increased. Bogale et al. (2016), assessed two tomato cultivars under water deficit conditions and observed a reduction of mass per fruit as water availability decreased.

For cherry tomatoes, the consumer does not always opt for larger fruits because of their specific uses but tend to observe more uniformity of the lot regarding color and size. However, the producer looks for larger fruits to obtain a higher yield.

Similar results were found by Soares et al. (2013), who observed in the tomato cultivar Super Marmande a reduction in pulp thickness with irrigation in deficit in relation to the crop evapotranspiration. by the F-test at $5 \%$ probability level. Subsequently, a response surface was performed when the interaction was significant, or a fitting to a linear and quadratic regression model when an isolated significance was observed by the factor. The analyses were performed with the software Statistical Analysis System version 8.2.

\section{RESULTS AND DISCUSSION}

The average fruit mass and pulp thickness presented an isolated significance for the water availability, with a fitting to a linear regression model. The highest average fruit mass (9.84 $\mathrm{g} \mathrm{fruit}^{-1}$ ) was observed in the water availability of $-4 \mathrm{kPa}$, with a $41 \%$ increase when compared to the water availability of $-44 \mathrm{kPa}$ (Figure $4 \mathrm{~A}$ ). The same occurs for the fruit pulp thickness, with the highest value of $3.9 \mathrm{~mm}$, which represents an increase of 18\% (Figure 4B).

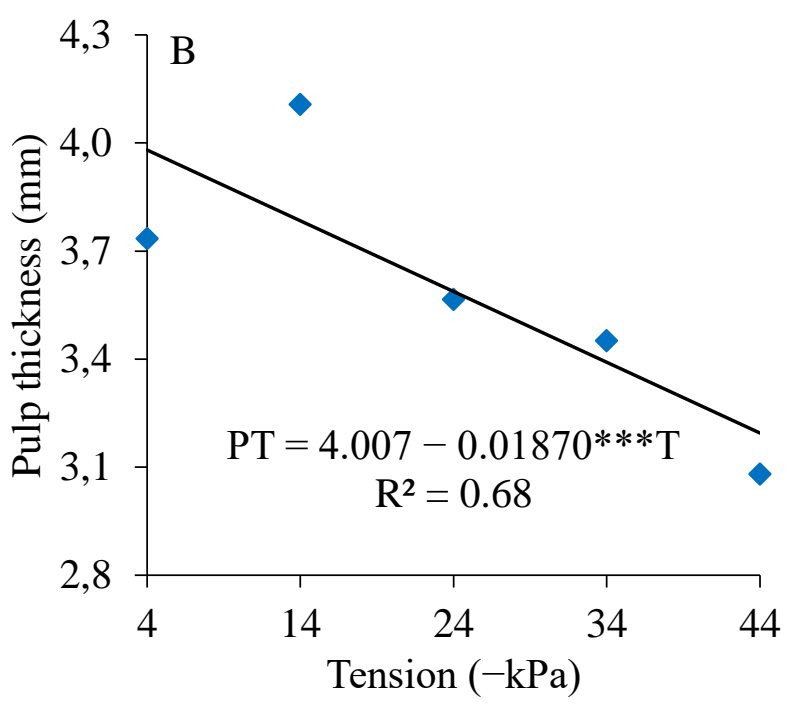

(B) of the cherry tomato cultivar BRS Iracema under water Fruit pulp thickness is relevant because it contributes with a higher mass per fruit. In this context, Resende et al. (2004) also pointed out that tomatoes with a larger pulp thickness lead to fruits with a higher firmness, which reflects in a longer shelf life, reducing possible waste due to the post-harvest perishability.

The transversal and longitudinal diameter of fruits presented an isolated significant difference for the water availabilities. A fitting to the linear regression model was observed for both diameters. The largest transversal (24.1 $\mathrm{mm})$ and longitudinal $(25.3 \mathrm{~mm})$ were observed in the water availability of $-4 \mathrm{kPa}$, with increases of 18 and $16 \%$ in relation to water availability of $-44 \mathrm{kPa}$, respectively (Figure 5). 

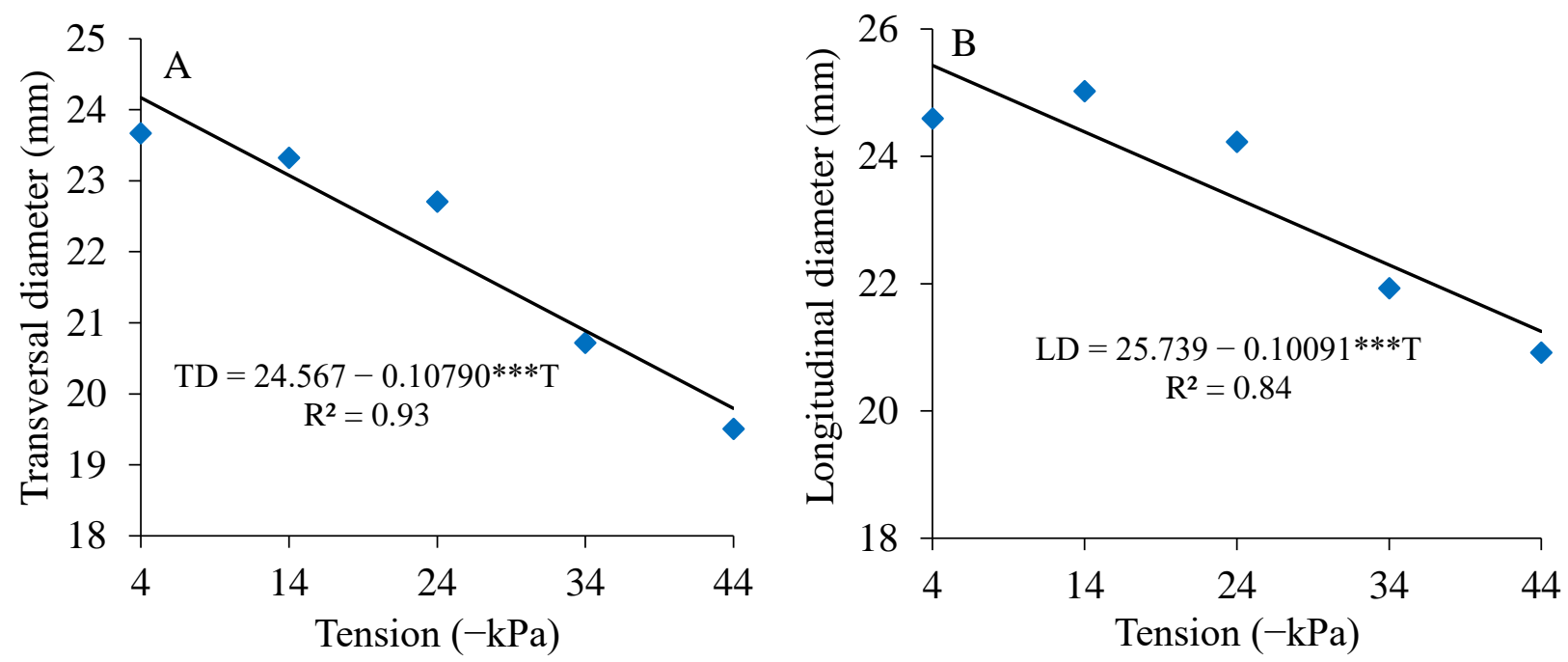

FIGURE 5. Transversal diameter (TD) (A) and longitudinal diameter (LD) (B) of the cherry tomato cultivar BRS Iracema under water availabilities in an Oxisol. ***Significant at $0.1 \%$.

The reduction in the transversal diameter of tomato with a reduction in the available water was also observed by Soares et al. (2011), Soares et al. (2013), and Candido et al. (2015), who worked with tomato under different water depths. Soares et al. (2011) also observed a reduction of the longitudinal diameter as the water availability reduced.

In the case of cherry tomato, the sale is carried out in differentiated packages, preventing the consumer to choose each fruit, as observed in other tomato groups. Therefore, criteria of uniformity for the lot contained in the package are possibly more adopted (Alvarenga, 2013).

Tomato fruit size depends on the rate and duration of cell growth since water availability directly influences the physiological processes of plants. A reduction in fruit size is justified by an increase in soil water availability, which also negatively affects the average fruit mass (Chevalier et al., 2011).

Possibly, the reduction in fruit size as soil water

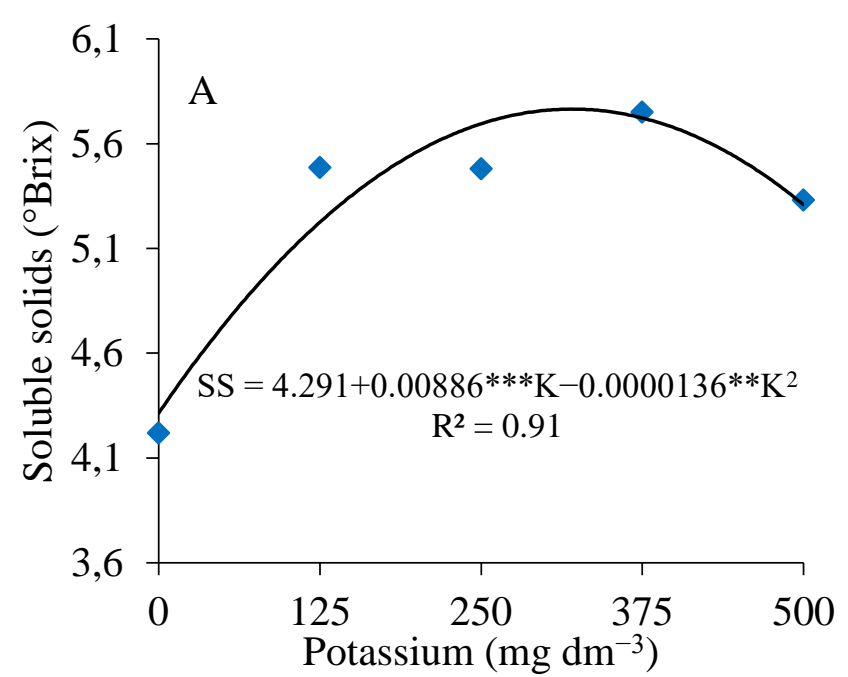

availability decreased was due to modifications in the source-drain relation since an increase in soil water tension (soil water potential more negative) restricts the absorption of water and nutrients. In addition, it can reduce the flow of elaborated sap to meet the demand for carbohydrates and mineral nutrients in the fruits and, consequently, reduce fruit size (Rodrigues et al., 2014; Coskun et al., 2016).

Fruit shape index did not present a significant difference for water availabilities and potassium doses, with a general average among fruits of 0.95 . This is possibly a characteristic more influenced by varieties and genotypes (Kuşçu et al., 2014; Nnungu \& Uguru, 2016) than water availability or potassium fertilization.

The total soluble solids presented an isolated significant difference for potassium doses, with a fitting to the quadratic regression model. In this case, the highest concentration of soluble solids $\left(5.7^{\circ} \mathrm{Brix}\right)$ was observed at a potassium dose of $326 \mathrm{mg} \mathrm{dm}^{-3}$, reaching a $25 \%$ increase in relation to the absence of potassium fertilization (Figure 6A).

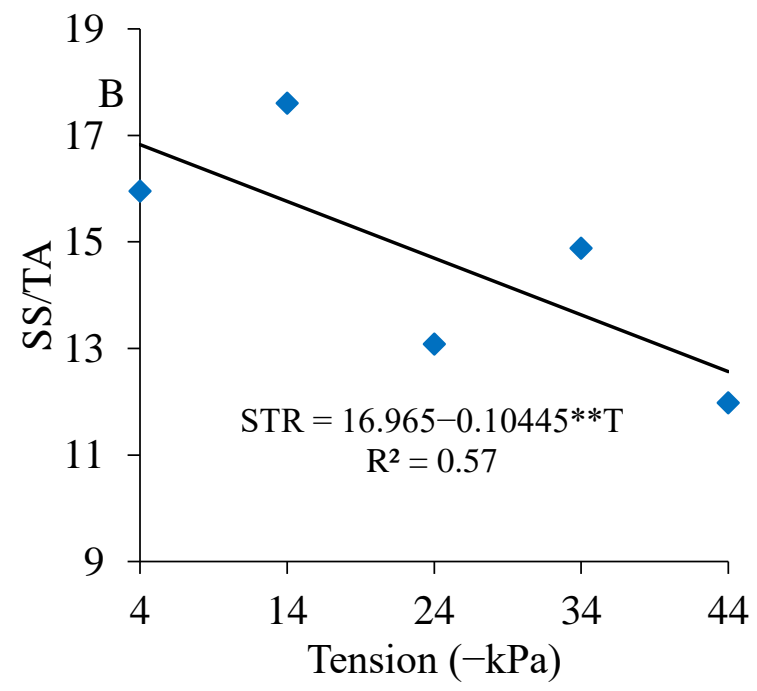

FIGURE 6. Total soluble solids (SS) as a function of potassium doses (A) and SS/TA ratio (STR) as a function of water 
availability (B) of the cherry tomato cultivar BRS Iracema cultivated in an Oxisol. *** and ** significant at 0.1 and $1 \%$, respectively.

The increased contents of soluble solids in fruits with the increased potassium fertilization occurs by the transport of sucrose in the phloem, which is favored by potassium. This, in turn, potentiates the transport from leaves to fruits, meeting the source-drain relation (Coskun et al., 2016; Martínez-Andújar et al., 2016). Rebouças Neto et al. (2016) worked with the hybrid Dominador F1 of the persimmon group and also observed an increase in the concentration of total soluble solids as potassium doses increased. According to Yuri et al. (2016), the content of total soluble solids is one of the main indicators to be analyzed to assess the commercial quality of tomato.

The total titratable acidity did not present a significant difference for water availabilities and potassium doses, with an average of $0.38 \mathrm{~g}$ citric acid 100 $\mathrm{mL}^{-1}$ of pulp. However, the SS/TA ratio presented an isolated significant difference for water availability, providing a better fit to the linear regression model. The highest ratio (16.5) was observed in the water availability of $-4 \mathrm{kPa}$, with a $25 \%$ increase when compared to that of $-44 \mathrm{kPa}$ (Figure 6B). Rebouças Neto et al. (2016) observed ratios between 7.5 and 12 for the hybrid Dominador F1 of the persimmon group.

According to Monteiro et al. (2008), a high SS/TA ratio indicates that tomato fruits have a combination of sugar and acid that correlate with a mild flavor, with sugars standing out in taste. According to Anthon \& Barrett (2003), the flavor in tomato fruits is the result of the interaction between soluble solids, acidity, and volatile components.

However, consumer preference may be related to the purposes given to cherry tomatoes, as some culinary dishes require fruits with more acidic flavors, which please the taste of consumers when considering the tomato along with other ingredients.

The content of vitamin $\mathrm{C}$ in cherry tomato fruits did not present a significant difference for water availabilities and potassium doses. The average value of vitamin $\mathrm{C}$ was $27.5 \mathrm{mg} 100 \mathrm{~g}^{-1}$ of pulp. According to Agbna et al. (2017), vitamin $\mathrm{C}$ is a vital antioxidant in the human diet, being one of the main factors that characterize the nutritional quality of fruits. In our research, the cherry tomato cultivar BRS Iracema showed a higher concentration of vitamin $\mathrm{C}$ when compared to other cultivars and varieties assessed in other researches.

Soares et al. (2013), for instance, quantified for the cultivar Super Marmande a concentration of vitamin C between 9 to $14 \mathrm{mg} 100 \mathrm{~g}^{-1}$ of pulp. Zhang et al. (2016) observed for the tomato cultivar Tunhe vitamin $\mathrm{C}$ values of 10 to $15 \mathrm{mg} 100 \mathrm{~g}^{-1}$ of pulp. In turn, Bogale et al. (2016) found to the cultivar Matina about $2 \mathrm{mg} 100 \mathrm{~g}^{-1}$ of pulp and for the cultivar Cochoro values of 3 to $8 \mathrm{mg} 100$ $\mathrm{g}^{-1}$ of pulp.

According to Ruggieri et al. (2016), the concentrations of vitamin $\mathrm{C}$ in tomato fruits range from 10 to $88 \mathrm{mg} 100 \mathrm{~g}^{-1}$ of pulp, including non-domesticated species. On the other hand, the range is generally lower in commercial cultivars, which present values of 10 to $40 \mathrm{mg}$ $100 \mathrm{~g}^{-1}$ of pulp, demonstrating that the variability of vitamin $\mathrm{C}$ in relation to the genotype is normal.

\section{CONCLUSIONS}

The structural quality, soluble solids, and SS/TA ratio of cherry tomato cultivated in pots with an Oxisol under a protected environment is influenced by water availabilities and potassium doses.

Fruit size was reduced as soil water availability decreased. Thus, water availability should be maintained close to the soil water potential of $-4 \mathrm{kPa}$ in order to obtain larger fruits. On the other hand, lower water availabilities with soil water potential of -34 and $-44 \mathrm{kPa}$ if the consumer market opts for smaller fruits.

The total soluble solids of cherry tomato had a higher concentration at a potassium dose of $326 \mathrm{mg} \mathrm{dm}^{-3}$. However, the total titratable acidity and the concentration and vitamin $\mathrm{C}$ were not influenced by water availability and potassium fertilization.

\section{REFERENCES}

Agbna GHD, Dongli S, Zhipeng L, Elshaikh NA, Guangcheng S, Timm LC (2017) Effects of deficit irrigation and biochar addition on the growth, yield, and quality of tomato. Scientia Horticulturae 222:90-101. DOI: https://doi.org/10.1016/j.scienta.2017.05.004

Alvarenga MAR (2013) Tomate: produção em campo, casa de vegetação e hidroponia. Lavras, Editora Universitária de Lavras, 2 ed. rev ampl.

Anthon GE, Barrett DM (2003) Thermal inactivation of lipoxygenase and hydroperoxytrienoic acid lyase in tomatoes. Food Chemistry 81(2):275-279. DOI: https://doi.org/10.1016/S0308-8146(02)00424-7

Bogale A, Nagle M, Latif S, Aguila M, Müller J (2016) Regulated deficit irrigation and partial root-zone drying irrigation impact bioactive compounds and antioxidant activity in two select tomato cultivars. Scientia Horticulturae 213:115-124. DOI:

https://doi.org/10.1016/j.scienta.2016.10.029

Candido V, Campanelli G, D'addabbo T (2015)

Castronuovo, D.; Perniola, M.; Camele, I. Growth and yield promoting effect of artificial mycorrhization on field tomato at different irrigation regimes. Scientia Horticulturae 187:35-43. DOI:

https://doi.org/10.1016/j.scienta.2015.02.033

Chen J, Kang S, Du T, Qiu R, Guo P, Chen R (2013) Quantitative response of greenhouse tomato yield and quality to water deficit at different growth stages. Agricultural water management 129:152-162. DOI: https://doi.org/10.1016/j.agwat.2013.07.011

Chevalier C, Nafati M, Mathieu-Rivet E, Bourdon M, Frangne N, Cheniclet C, Renaudin, JP, Ge'vaudant F, Hernould M (2011) Elucidating the functional role of endoreduplication in tomato fruit development. Annals of Botany 107(7):1159-1169. DOI: https://doi.org/10.1093/aob/mcq257 
Coskun D, Britto DT, Kronzucker HJ (2016) The nitrogen-potassium intersection: membranes, metabolism, and mechanism. Plant, Cell \& Environment 40(10):1-13. DOI: https://doi.org/10.1111/pce.12671

EMBRAPA - Empresa Brasileira de Pesquisa Agropecuária (1997) Manual de métodos de análise de solo. EMBRAPA-SPI, 2 ed.

Kuşçu H, Turhan A, Demir AO (2014) The response of processing tomato to deficit irrigation at various phenological stages in a sub-humid environment. Agricultural Water Management 133:92-103. DOI: https://doi.org/10.1016/j.agwat.2013.11.008

Littell RC, Mott GO (1975) Computer assisted design and analysis of response surface experiments in agronomy. Soil and Crop Society of Florida Proceedings 34:94-97.

Lúcio ADC, Sari BG, Pezzini RV, Liberalesso V, Delatorre F, Faé M (2016) Heterocedasticidade entre fileiras e colheitas de caracteres produtivos de tomate cereja e estimativa do tamanho de parcela. Horticultura Brasileira 34(2):223-230. DOI: http://dx.doi.org/10.1590/S0102-053620160000200012 Marim BG, Silva DJH, Guimarães MA, Belfort G (2005) Sistemas de tutoramento e condução do tomateiro visando produção de frutos para consumo in natura. Horticultura Brasileira 23(4):951-955. DOI: http://dx.doi.org/10.1590/S0102-05362005000400018

Martínez-Andújar C, Albacete A, Martínez-Pérez A, Pérez-Pérez JM, Asins MJ, Pérez-Alfocea F (2016) Rootto-shoot hormonal communication in contrasting rootstocks suggests an important role for the ethylene precursor aminocyclopropane-1-carboxylic acid in mediating plant growth under low-potassium nutrition in tomato. Frontiers in Plant Science 7(1782):1-16.

Monteiro CS, Balbi ME, Miguel OG, Penteado PDS, Haracemiv SMC (2008) Qualidade nutricional e antioxidante do tomate "tipo italiano". Alimentos e Nutrição Araraquara 19(1):25-31.

Nnungu SI, Uguru MI (2016) Evidence of association among floral and fruit traits and its implication on fruit size and shape in tomato (Solanum lycopersicum). Australian Journal of Crop Science 10(9):1288-1296. DOI: http://dx.doi.org/10.21475/ajcs.2016.10.09.p7730

Pereira MTJ, Silva TJA, Bonfim-Silva EM (2016) Soil water content and wood ash fertilization on the cultivation of gladiolus. Revista Brasileira de Engenharia Agrícola e Ambiental 20(4):350-356. DOI:

http://dx.doi.org/10.1590/1807-1929/agriambi.v20n4p350356

Pervez H, Ashraf M, Makhdum MI (2004) Influence of potassium nutrition on gas exchange characteristics and water relations in cotton (Gossypium hirsutum L.). Photosynthetica 42(2):251-255.

Pregnolatto W, Pregnolatto NP (1985) Normas analíticas do Instituto Adolfo Lutz.

Rebouças Neto MDO, Azevedo BMD, Viana TVDA, Mesquita JB, Carvalho MA, Carvalho LC (2016) Potassium fertilization via fertigation and conventional application on quality of tomato fruits. Revista Brasileira de Engenharia Agrícola e Ambiental 20(10):913-917. DOI: http://dx.doi.org/10.1590/18071929/agriambi.v20n10p913-917
Resende JM, Chitarra MIF, Maluf WR, Chitarra AB,

Saggin Júnior OJ (2004) Atividade de enzimas pectinametilesterase e poligalacturonase durante o amadurecimento de tomates do grupo multilocular. Horticultura Brasileira 22(2):206-212. DOI: http://dx.doi.org/10.1590/S0102-05362004000200009

Rocha MQ, Peil RMN, Cogo CM (2010) Rendimento do tomate cereja em função do cacho floral e da concentração de nutrientes em hidroponia. Horticultura Brasileira 28(4):466-471. DOI: http://dx.doi.org/10.1590/S010205362010000400015

Rodrigues GSO, Negreiros MZ, Lopes WAR, Grangeiro LC, Lima JSS (2014) Growth and partitioning of assimilates in tomato trees due to the different kinds of mulching. Revista Caatinga 27(2):10-17.

Ruggieri V, Bostan H, Barone A, Frusciante L, Chiusano ML (2016) Integrated bioinformatics to decipher the ascorbic acid metabolic network in tomato. Plant Molecular Biology 91(4-5):397-412.

Sari BG, Lúcio ADC, Santana CS, Lopes SJ (2017) Linear relationships between cherry tomato traits. Ciência Rural 47(3):1-7. DOI: http://dx.doi.org/10.1590/0103$8478 \mathrm{cr} 20160666$

Soares LAA, Brito MEB, Silva ECB, Sá FVS, Araújo TT (2013) Componentes de produção do tomateiro sob lâminas de irrigação nas fases fenológicas. Revista Verde de Agroecologia e Desenvolvimento Sustentável 8(3):84-90.

Soares LAA, Lima GS, Brito MEB, Sá FV, Araújo TT (2011) Crescimento do tomateiro e qualidade física dos frutos sob estresse hídrico em ambiente protegido. Revista Verde de Agroecologia e Desenvolvimento Sustentável $6(3): 203-212$.

Viol MA, Carvalho JA, Lima EMC, Rezende FC, Mattos RWP, Rodrigues JLM (2017) Déficit hídrico e produção do tomate cultivado em ambiente protegido. Revista Brasileira de Agricultura Irrigada 11(1):1244-1253. DOI: http://dx.doi.org/10.7127/rbai.v11n100580

Yuri JE, Costa ND, Lima MACD, Resende GMD, Ferreira TD, Silva MC (2016) Mini tomato cultivars for the Submid São Francisco Valley, Brazil. Revista Caatinga 29(4):1015-1020. DOI: http://dx.doi.org/10.1590/198321252016v29n427rc

Zhang H, Xiong Y, Huang G, Xu X, Huang Q (2016) Effects of water stress on processing tomatoes yield, quality and water use efficiency with plastic mulched drip irrigation in sandy soil of the Hetao Irrigation District. Agricultural Water Management 179:205-214. DOI: https://doi.org/10.1016/j.agwat.2016.07.022

Zia-ul-Hassan, Kubar KA, Chhajro MA, Kandhro MN, Jamro GM, Talpur KH Talpur N (2016) Response of Tomato (Lycopersicon esculentum L.) at Varying Levels of Soil Applied Potassium. Journal of Basic and Applied Sciences 12:198-201. 